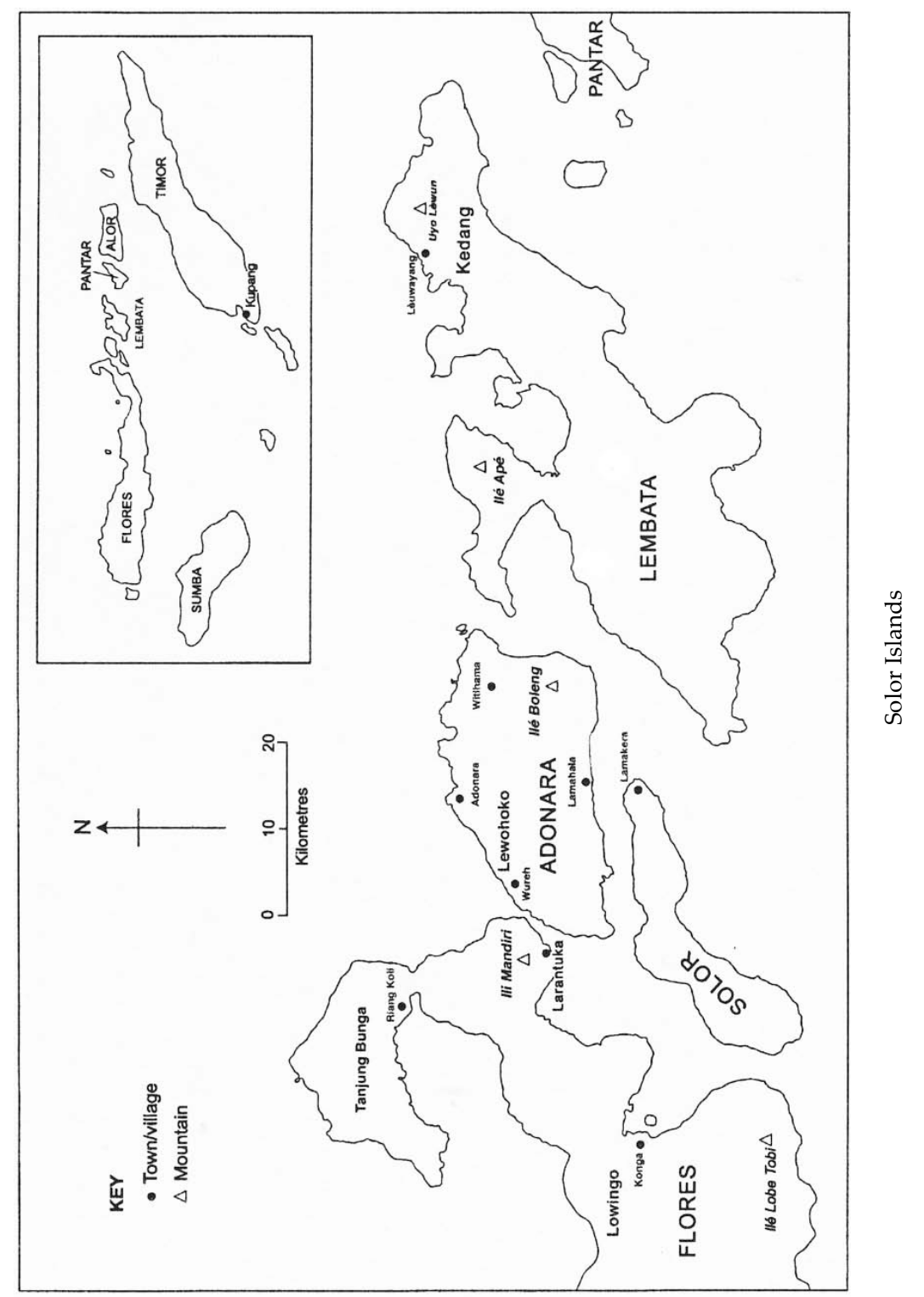


R.H. BARNES

\section{A temple, a mission, and a war Jesuit missionaries and local culture in East Flores in the nineteenth century}

In 1851 as an earnest to cover a debt incurred by its colony in East Timor, the government of Portugal ceded control of its 'possessions' on Flores, Solor, Adonara, Lembata, Pantar and Alor in eastern Indonesia to the Netherlands. In 1859, after lengthy negotiations and the payment of a substantial sum to Portugal, the Netherlands assumed formal possession of these islands (Heyman 1895:37; Ezermann 1917:881). A condition imposed by the Portuguese was that those inhabitants of these islands who were Catholic (primarily those of Larantuka and Konga, Flores and Wureh, Adonara) would remain Catholic. This condition was secured in article 10 of the 1859 treaty which guaranteed religious freedom on both sides. ${ }^{1}$ Despite the fact that many Netherlanders were Catholic, the Netherlands Indies government represented essentially a Protestant power in the region, and most of its colonial officers in the Timor Residency were Protestant.

Not only did this shift in suzerainty initiate a series of transformations of profound local importance, but it also involved European and local figures in challenges which were often beyond their immediate ability to control or fully to comprehend. Such confusions had lethal or potentially lethal results, among them threats to local communities and to the town of Larantuka, Flores.

1 Tractaat 1860:3; Heyman 1895:86; Larantuka 1962-68:2-3. A draft treaty of 1854 guaranteed religious freedom for Roman Catholics in those regions ceded by the Portuguese to the Dutch, but said nothing about those parts of Timor conceded in return by the Dutch to the Portuguese. The Netherlands' Second Chamber objected to this asymmetry, and the Portuguese and Netherlands governments compromised on the wording of article 10, which simply guarantees freedom of religion in all territories. It is doubtful that any of those involved in the negotiations was thinking of the religious freedom of 'heathens' at the time (Heyman 1895:22-3; Ezermann 1917:881-9; Steenbrink 2003:71-3).

R.H. BARNES is Professor of Social Anthropology at the University of Oxford, where he also obtained his DPhil degree. A specialist on eastern Indonesia, he is the author of Kédang; A study of the collective thought of an eastern Indonesian people, Oxford: Clarendon, 1974, and Sea hunters of Indonesia; Fishers and weavers of Lamalera, Oxford: Clarendon, 1996. Professor Barnes may be reached at robert.barnes@anthro.ox.ac.uk. 


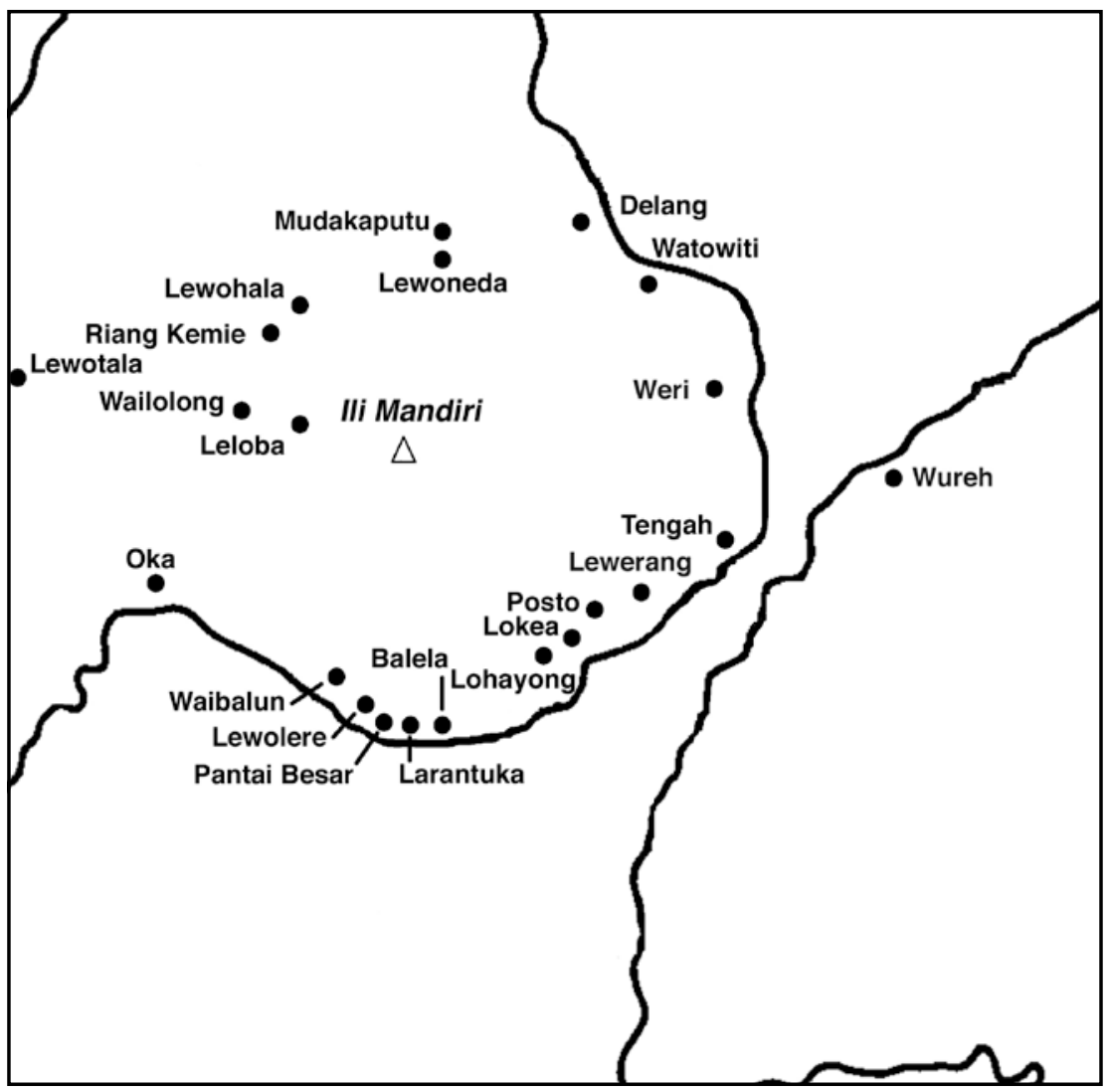

East Flores

\section{Beginnings of the Dutch mission in Larantuka}

The Netherlands formally, if officially only temporarily, took over Larantuka on 16 December 1851. One of the later Jesuit priests related that the population was incensed by this Dutch takeover of the Portuguese possessions and regarded themselves as having been sold for money and treated as slaves. The Resident Baron van Lynden was sent to Larantuka to explain the transfer to a startled population. It required the mediation of the priest Fra Gregorio Barreta from Dili, whom the Resident Baron van Lynden had had the foresight to bring with him, to calm them. Some years later, in March 1860, for reasons which remain unclear, but of course just after the transfer became permanent, circa 1,000 mountain people attacked the Dutch fort in Larantuka, although they were beaten back with the loss of 28 dead and 90 wounded (Larantuka 1962-68:3; Heynen 1876a:59-61; Steenbrink 2003:71, 73). 
One consequence of the shift of control was that priests from the Portuguese holdings on Timor no longer visited Larantuka. Don Gaspar, brother of the Raja of Larantuka Don André and himself later raja, directed via the Resident of Timor a request of the Netherlands Indies government that it provide a Dutch priest. $^{2}$ In a letter of 12 September 1859, that government turned to the Apostolic Vicar of Batavia to see if a priest were available for Larantuka (Steenbrink 2003:71-3, 292-3). The first two Dutch priests in Larantuka served only briefly, from 1860 to 1861 and from 1861 until 1863, due to ill health. The first Jesuit priest arrived in 1863. The first of these three men, Jan P.N. Sanders, said of then Raja André that everything he had heard about him was extremely sad and not encouraging. For himself alone Don André required a hundred guilders of opium, no doubt per year (Larantuka 1962-68:4-5, 8; Steenbrink 2003:300). Many aspects of worship and conduct in Larantuka were not to the missionaries' liking. For example Don André had four wives or concubines, his brother and successor Gaspar had five, a further brother Mingo $^{3}$ had three, while yet another brother Don Kinu, father of a future raja and favourite of the mission, had five (Larantuka 1962-68:19). Both Gaspar, 'a very dangerous subject', and Mingo were said to have had several murders on their consciences. Like his older brother André, Mingo was addicted to opium. Kinu, 'a simple village head', was for a time the head of a band of pirates (Larantuka 1962-68:11).

Slaughtering of supposed witches, the exposure in trees of the corpses of people killed in battle, and polygamy upset the missionaries. What caused them the most offence perhaps were the traditional temples. They and their successors called them (in Malay) rumah setan ('houses of the devil') and rumah pemali ('forbidden houses'). ${ }^{4}$ The latter term is more neutral, and in local Malay means approximately 'sacred houses', that is temples. In local Malay today it is more common to call them rumah berhala, but generally without the Muslim-inspired significance of the literal meaning of this term, that is 'house of idolatry', although the more common term in both Larantuka Malay and the local Lamaholot is korke or some variant. ${ }^{5}$ Yet certainly the missionaries regarded the practices associated with them as idolatrous. Sanders expressed horror at the 'obscenity' of the carvings and objects found in them,

2 By the nineteenth century the family name of the family of the rajas of Larantuka had become Diaz Vieira Godinho.

3 This Mingo or Ilé died in 1872. He is not to be confused with his half brother Dominggo or Ence, who became raja.

4 Heynen (1876b:10) claims that the expression 'Satan's house' and also the expression 'devil's service' were local usage; if this is so, it was only in Larantuka Malay.

5 Pampus (1999:27) says that korke cannot be a genuine Lamaholot word because of the $r k$ combination and notes that in Lewolema it is pronounced kokĕ or koko. Nevertheless this pronunciation is frequently encountered. 
including the heads of enemies killed in battle. They were gathering places in times of war and calamity. There the people requested support from the spirit in times of extreme need. 'In one word it is what one can call a temple' - that is, not a church. The ordinary man and woman was not permitted to enter such a temple. So wrote Father Sanders in 1861 (Larantuka 1962-68:31-2).

Raja André died on Easter Day 1861. It was generally assumed that his illness and death was caused by Father Sanders (Larantuka 1962-68:25-6). Mingo had persuaded his brother the raja to rebuild the korke associated with the realm of Larantuka which had for years been a dilapidated hovel and called on the mountain people to rebuild it. Father Sanders then expressed his opposition to this development to Don André, who promised that he would stop the building. Father Sanders wrote to the bishop about how painful he found the discovery that the raja had encouraged work on the temple. Since arriving, he had acquired the impression from the behaviour of some of the leading men that they had pressed for a priest not out of sincerity, but as a hidden push against the Dutch government. Sanders interpreted the plan to rebuild the temple as a move to strengthen ties with the mountain people as a counterweight to the Dutch government.

He pressed the raja repeatedly for assistance in building a chapel, which the raja promised to do, but there were always unexpected hindrances. One afternoon he heard in the distance a great commotion of mountain people approaching carrying great loads. Soon hundreds appeared loaded with large beams and other pieces of wood and bamboo. At first he thought that building material for his chapel was finally materializing, but then he discovered, as the loads were carried past him, that they were intended for rebuilding the korke. ${ }^{6}$

\section{Cultural and historical background}

The phrase 'mountain people' as was subsequently specified applies to those referred to in the nineteenth-century records and still today as 'behind the mountain', that is the Ili Mandiri which looms over Larantuka. From Watowiti in the north, west of the mountain and south to Leloba are a series of villages collectively referred to as Baipito (Dietrich 1997:61-2). By a genealogical charter they shared a common mythical ancestor with the Raja of Larantuka and formed a significant part of his realm (Dietrich 1995:128-9). This relationship was only vaguely understood by the first Dutch missionaries to Larantuka.

6 Larantuka 1962-68:32-3; Steenbrink 2003:100, 314. In a sacred grove between the hamlets of Lokea and Lohayong, 100 steps from the sea and 500 from the fort, and thus in the centre of Larantuka (Larantuka 1962-68:66-7). 
Another feature of considerable significance in Lamaholot culture which the pioneers of the mission would not have understood is that the population is divided into an extremely loose set of alliances termed Demon, and focused on the Raja of Larantuka, and another termed Paji. Most of the population had not accepted either Christianity or Islam by 1860, but the Paji belonged to one or another of five Muslim principalities called in Lamaholot Solor Watan Lema or the Five Solor Coasts, all tiny coastal statelets, the largest of which was that of Adonara located on the north coast of the island of that name. The other four Muslim statelets possessed little more territory than that immediately adjacent to the villages in which they were located, although Lamahala claimed some territory elsewhere, and the Raja of Lamakera had claims to eastern Solor. The Raja of Adonara, however, had at least nominal control over regions of northeastern and even part of western Adonara, the northern tip of eastern Flores, and parts of Lembata. The dependencies of the Paji rajas and the Raja of Larantuka were thus interspersed in an irregular checkerboard pattern across eastern Flores, Solor, Adonara and Lembata. So stood the situation in 1860, and so it remained until the bureaucratic consolidations of the Netherlands Indies government in the twentieth century. Oral tradition, however, depicts a very fluid history of the geographical distribution of the Demon and Paji populations in the ancient past. Small wars and head taking sometimes occurred across the divide, but wars also occurred within each division, and there were very occasional alliances across the divide. The division also had a mythical charter (Arndt 1938).

Dutch influence in these islands did not appear for the first time in 1851. The Portuguese had been present in one form or another since early in the sixteenth century, and the Dutch established a presence when they took the Portuguese fort at Lohayong, Solor in 1613, without being able to drive the Portuguese completely from the region. In time the Portuguese were left in alliance with the Demon and the Raja of Larantuka. The Dutch established and maintained with differing degrees of attention alliances with the Muslim rajas of the Solor Watan Lema and by an implication, of which perhaps they were not fully conscious, with Islam. After the murder of Begu, Raja of Adonara, in 1850 by people from Lewohoko to the west, the Dutch became increasingly closely tied to successive rajas of Adonara (Barnes 2005a, 2005b).

What Don André may have thought when he learned that his lands were to be sold to the Dutch East Indies may be imagined. The Raja of Larantuka, himself a Catholic, must have been astonished to discover that his co-religionists and allies would think to sell his lands and his people, including himself, to another power. As far as he was concerned, he was sovereign. Sanders found that the leading men of Larantuka thought that there were no genuine Catholics in the Netherlands Indies, but just 'new Christians', that is Protestants. This interpretation was hardly pleasing to the Dutch mis- 
sionaries, who looked with alarm at what they regarded as the lax form of Catholicism left behind by the Portuguese (Larantuka 1962-68:32). To André his land and people had been delivered to the allies of enemies of many centuries, namely the Muslim and Paji principalities. Remarkably, I have uncovered no contemporary comment by anyone on this implication. Whether in conscious or unconscious continuation of these ancient patterns, the secular, mostly Protestant, Dutch authorities stationed in these islands continued to maintain close political and personal ties with the Muslim rajas, particularly the rajas of Adonara, and often strained and sometimes openly hostile relations with the rajas of Larantuka. Their relationships with individual missionaries varied between friendly and cooperative to tense, competitive and sometimes harshly critical on both sides. However, the missionaries and the civil officers were constrained to cooperate wherever they could.

\section{Temples}

Sanders offers no explanation for the dilapidated state of the temple of the realm, although he attributed a political motive to its rebuilding. In the traditional Lamaholot village structure a village should have a korke for religious ceremonies and an accompanying meeting house or balé. Ideally both structures should stand in the centre of the village, often opposite the clan temple of the clan which claims the status of lord of the land. The lord of the land was also lord of the temple, taking a leading role in its affairs (Vatter 1932:93). Arndt (1951:79) states that if the temple is located outside the village, then it marks the former village site. It was usual for a dancing area, nama, to be located before the temple, often surrounded by a low stone wall of stacked, irregular flat stones held in place by a row of similar slabs set perpendicularly into the ground. Before the temple was usually found a pile of stones, nuba nara, of religious significance. To this extent the realm of Larantuka, although in its centre speaking a particular form of Malay with much Portuguese admixture, was merely replicating a Lamaholot cultural pattern. Offerings and addresses to bipartite Divinity, Lera Wulan (Sun Moon) and Tana Ekan (Earth Region), are made in the korke. When I first began research in Kédang, Lembata in 1969 the village of Leuwayang had no village temple because of disputes within the village, although there was a tiny structure representing it. Such temples were strongly opposed then by the Catholic mission and by the government. In 1998, the village sported a proud new and quite large temple. When I arrived in Witihama, Adonara in September, 2000 to begin field research there, the community was beginning to erect a village temple. Haji Muktar, who took the leading role in organizing its building, explained to me that there had been no temple in living memory and that he and his 
father had watched the remains of the last disappear. ${ }^{7}$

I wrote about the temple and the renewed village harvest ritual in the village of Leuwayang, which was the occasion of my visit in 1998, in terms of ritual resurgence and cultural revival, following rhetoric used in the village at the time (Barnes 2005c). I encountered much the same interpretation in Witihama in 2000, and while attending a conference in Kupang, Timor in July, 2007, I listened to comments by local academics about recent efforts by the government to encourage communities to revive their adat (customary) practices and institutions. These attitudes represent a reversal of those adopted by the government in the 1970s. Bubandt (2004:16) has coined the phrase 'new politics of tradition' for such developments.

I think that these interpretations are correct, but there is evidence that they are not a complete statement of the situation. In fact there is clear evidence that in the more distant past too, in many villages, including those behind the Ili Mandiri, village temples have been left to deteriorate over long periods before being rebuilt. It is reasonable to suppose that both the pattern of neglect and the efforts to renew such structures usually reflect political tensions within villages. The revival of the temple in Witihama triggered another expression of a conflict between two important descent groups that Arndt (1940:149) had already encountered in the 1930s (see also Barnes 2007). The historical pattern is perhaps best expressed by Rouffaer in his field notes. ${ }^{8}$ After describing the decorations on the roof beam of a temple on Adonara, he remarked that otherwise the koerke (as he spelled it) are very insignificant open grass huts on four poles lacking all decoration, which were not kept up, but allowed to become dilapidated. Only once the temple had disintegrated was there a great feast of rebuilding and a new temple. More care was taken of the balé. So a possible interpretation is that the long neglect of a temple and its eventual rebuilding is an established pattern, holding over the centuries and independent of political fashions. It is possible to speculate too that any decision to rebuild calls into play long-standing political factors within the community, but that the immediate reason for rebuilding will vary from place to place and time to time.

\section{Further developments}

In 1862 Sanders's replacement Caspar J.H. Franssen permitted the new Raja Gaspar to build a structure for the mountain people provided that no food

7 Except for a single post, which remains.

8 'Aantekeningen van G.P. Rouffaer over zijn [tweede] Indische reis, 1909-1911, deel 10 Kleine Timor-eilanden', pp. 55-6, in: KITLV, Collectie 40 G.P. Rouffaer, H 673. 
was offered to the ground and that it did not serve as a 'devil's house'.

Don Gaspar gave me the assurance that this house where his ancestors are buried has nothing to do with idolatry and that this house would only serve as a caravansary when on the one hand the mountain people could not return to the village and on the other hand could not camp in the wind and rain. A house for the population must thus exist. (Larantuka 1962-68:67.)

Subsequently, while forcing his way through the brush in the sacred grove in search of beams that could be used for a church and school, he discovered a second building, twenty-five paces beyond the house just described. This turned out to be the real temple, the 'Ili Mandiri House'. He deemed himself to be the first person to see it other than the three initiates who cared for it. The suddenly wakened guardian tried to keep him away from it, but he forced his way in, where he found a kettledrum, a gong, an elephant tusk and other objects, as well as the remains of a sacrifice. He left determined to bring an end to this 'devil's service'. The raja eventually agreed to get rid of the temple. Franssen also forbade bringing offerings there. He learned too that there was a temple in the Christian village of Konga and another on the crown of Ili Mandiri, and determined to get rid of them (Larantuka 1962-68:68-71).

In July, 1863, Franssen wrote that during a visit to Larantuka the Resident Isaac Esser was asked in the presence of Raja Gaspar by two or three Christian heads for permission to build the temple, Franssen added 'naturally for the raja'. The Resident asked in turn why permission was necessary and was told that it was because the priest had forbidden it. To this reply the Resident is reported as having said that the priest may forbid such things in the church, but outside the church he had no right to give orders. Raja Gaspar, however, said that the Resident had not spoken about the priest, but that when the Resident was not present, the civil commissioner of Larantuka had repeatedly asked them whether the priest had forbidden building the temple. Franssen held that the raja had claimed that he could not continue to be raja without the temple (Larantuka 1962-68:181-2). Heynen (1876a:34) later wrote that the rumah setan or 'devil's house' was maintained near the raja's house after his 'conversion' for reasons of state. Resident Esser had once tried to convert the raja to Protestantism and was thought by Franssen to be anti-Catholic and determined to establish a Protestant mission in Larantuka (Larantuka 196268:106, 183-4; Steenbrink 2003:98).

The first Jesuit priest, Gregorius Metz, arrived on 17 April 1863, and eventually replaced Franssen, who left in October of the same year because of bad health (Steenbrink 2003:77). In 1867 Raja Gaspar became involved in a war with mountain people who had murdered eight of his subjects. In revenge, people from Larantuka shot four mountain people. In turn, mountain people threatened to attack his compound. He responded by placing cannons before 
and behind his house (Larantuka 1962-68:259). In 1873 Father Metz commented that the 'heathens' had their temples, even in the raja's village, but the Christians should not be allowed to take part, as Raja Gaspar had often promised, but he (Gaspar) lacked energy and genuine cooperation - which might be another way of saying that he was torn between conflicting loyalties and responsibilities. Metz said however that he did not think the raja believed in these things. Metz later had an opportunity to strike back. Because of a drought which was damaging the crops, the raja and his council came to him to request a prayer for rain. Metz agreed on condition that the Christians would cease to honour the devil and with the raja leading them solemnly swear off all devil worship. Metz was pleased that Don Gaspar appeared to agree. He was not pleased that in the same year Gaspar had taken another wife, who moreover was Muslim (Larantuka 1962-68:334).

Heynen describes the lord of the land as taking the first place after the raja. He was spoken of as the raja tanah or 'king of the land'. This position is not to be confused with the important raja kedua or 'second raja', descendants of outsiders who had no such claims on the land. Heynen (1876c:80-1) represents the two as forming a diarchy with the raja possessing the highest temporal power, and the lord of the land having the highest spiritual power. Dietrich (1997:36, 120-1) sets out the difficulties with the sources in determining just who exercised this office for the realm. Furthermore, he comments, 'Heynen's whole discussions of korke and tua tana ['lord of the land'] suffer from the fact that he has obviously confused the korke in Lokea (korke Lewonama [that is, the temple of the realm of Larantuka]) and in the ward of Larantuka, perhaps not the least caused by the fact that "Larantuka" is used for the name of the town, for the principality and for a limited ward' (Dietrich 1997:158, note 151). Nevertheless, Dietrich's subtle presentation and analysis of the evidence for the structure of the Larantuka realm do substantiate Heynen's statement that in the Kingdom of Larantuka, religion was intimately woven into the state and that they penetrated each other (Dietrich 1997:122-6; Heynen 1876c:7980). It follows from this circumstance that an earnestly Christian raja of Larantuka could not simply abolish the temple and associated rituals without disrupting his relationships with non-Christian subjects, however much he might neglect them. Some of the vacillating behaviour that the missionaries complained about derived from the fact that mid-nineteenth-century rajas of Larantuka were caught between conflicting responsibilities which were beyond their control.

\section{Raja Dominggo}

Raja Don Gaspar died at the age of 57 on 24 January 1877 from dysentery. Although the priests hoped that his nephew, the seventeen-year-old Lorenzo, 
would be appointed to replace him, the government chose another of the set of brothers, Gaspar's half-brother Don Dominggo, whom the missionaries, although they thought well of him personally, regarded as illegitimate, because his mother was one of his father's wives whom he had not married in church. ${ }^{9}$ Metz resigned himself to preparing Lorenzo to take over when he came of age and, as he promised, Dominggo stepped down. His first step was to enlist Lorenzo as a teacher in the school he had started (Larantuka 196268:384).

Metz felt that Civil Commissioner E.F. Kleian, who served with an interruption from June 1874 until March 1885, was consistently hostile to Catholics. He was also a great friend of the Muslim Raja of Adonara. Kleian, so Metz thought, brought Resident C.M.G.A.M. Ecoma Verstege to share his views. On a trip to Maumere in 1878 which Father Cornelius Henricus Antonius ten Brink, then stationed in Maumere, agreed to accompany, the Resident could find nothing good in the doings of the Christians of Larantuka and nothing to criticize about the 'heathens' and the Muslims. Later ten Brink went to Larantuka to ask Metz to write to the Resident to explain to him how he had been deceived by Kleian, which Metz did. The Resident was not pleased, but the friendship between them was not broken. The priests continued to lodge with him in Kupang, and he with them when he was in Larantuka. Kleian for his part registered complaints with the Resident about Metz. Furthermore Metz blamed Kleian for the choice of the illegitimate Dominggo as raja (Larantuka 1962-68:395-6).

Soon thereafter Metz had a new worry. The annual west monsoon rains, upon which the harvest depends, did not appear in good time. Fortune tellers attributed the failure of the rains to the fact that the Europeans had caused several temples in Larantuka to be torn down and had forbidden the sacrifice of goats and pigs (to ask for rain); further they had climbed the mountain and made a fire at the top, causing the mountain to be desecrated and no longer to listen, and finally they placed God in the naked heavens, exposed to heat

9 Larantuka 1962-68:375-7; 'Kort verslag van den stand van zaken en van het personeel in de residentie Timor over de maand Maart 1877', 3-4-1877, in: Nationaal Archief, The Hague (hereafter NA), Ministerie van Koloniën (hereafter Koloniën), Mailrapporten, 2.10.10, 1877, no. 282, fiche 415. Initially the government expected to replace Gaspar with Lorenzo, but decided otherwise after Civil Commissioner Kleian reported that the heads, that is those who filled traditional posts of leadership within the kingdom of Larantuka, wished to pass over Lorenzo who was too young for the government, which had fallen into decay due to Gaspar's indolence. The Resident said of Don Gaspar that his death 'cannot be regarded as a loss' ('Kort verslag van den stand van zaken en van het personeel in de residentie Timor over de maand Maart 1877', 3-4-1877, in: NA, Koloniën, Mailrapporten, 2.10.10, 1877, no. 282, fiche 415; 'Kort verslag omtrent den stand van zaken en het personeel in de residentie Timor over de maand Junij 1877', 3-7-1877, in: NA, Koloniën, Mailrapporten, 2.10.10, 1877, no. 534, fiche 452). 
and rain, whereby the rains were made impossible. In fact, Father Meijer had placed a cross and picture of Christ at the top of the mountain. A village head then went to all the villages around the Ili Mandiri to persuade them of his plan to take steps to end the catastrophe which threatened them. According to the Resident Ecoma Verstege the village head in question was the head of Leloba. ${ }^{10}$ The coastal dwellers remained unaware of the danger which was so near.

Father Metz wrote to the bishop that however much they exerted themselves to keep Christian villagers from all devil worship, they nevertheless judged it necessary to permit the large pemali temple to continue to stand. As it was a sign of the kingship of the raja, the mountain people recognized their ruler through it. When there were calamities the mountain people came to the temple, making offerings there after receiving permission from the raja. However, when people from the coastal village of Bebalon (today's Waibalun), where some Christians lived but which was mostly 'heathen', came to sacrifice some goats in order to request rain, they forgot to ask permission from the raja and also took a few goats from the Christians. Presumably tradition permitted them to take goats in such circumstances. The Christians resisted, almost leading to a fight, which the raja came quickly enough to prevent. The people of Bebalon claimed that by making the sacrifices, they had prevented the mountain people from coming down to murder the white men and all the Christians. When the raja investigated, he discovered that these were not empty words and that the mountain people had indeed decided to respond to their 'superstitions' and to carry out their plan.

Unfortunately, the Christians had few weapons and little ammunition, which the mountain people knew. Formerly everyone had been armed, but when the Dutch had put a small military force in Larantuka so that they no longer feared an attack, they sold their arms. Then when the force was withdrawn, they remained confident because the Dutch civil commissioner and the priests remained in Larantuka. Although they still bought powder and weapons, they did so mostly in order to trade them in the mountains. Then, unexpectedly, the Dutch imposed a prohibition on the importation of powder and weapons. The Christians were under the immediate observation of the government and could obtain no more weapons, whereas further away smuggling of weapons continued unhindered. In consequence the mountain people came to be much better provided with weapons than the raja and the coastal Christians.

10 Ecoma Verstege, 'Verslag omtrent de reis van den resident van Timor naar Soemba, Endeh en de Solor Eilanden, van den 27 Maart t/m den 7 April 1878 per Zr.Ms. stoomschip Samarang', Kupang, 10-4-1878, in: NA, Koloniën, Mailrapporten, 2.10.10, 1878, no. 341, fiche 499; Dietrich 1983:55, note 28. 
When the Resident visited Larantuka, the situation was pointed out to him, and he replied that he could always give the raja permission to purchase weapons. Raja Dominggo asked for 200 rifles with powder and lead to be ordered from Makassar. He sent this request through Civil Commissioner Kleian, who did not regard the threat as so great and gave the proposal little support. The raja then turned to Metz and asked him to place the order, because the raja thought that he, the raja, had little credit in Makassar. Metz placed the order for him after taking goods in security. Metz then wrote the Resident privately to tell him that he had placed the order, but that of course it could not be filled without his permission. He also elaborated on the circumstances and said that it would be a good idea to send a cruiser (kruisboot) while waiting for the arms to arrive. Resident Ecoma Verstege did station a warship off Larantuka, but claimed (despite his earlier statements) that he lacked the authority to authorize the purchase of weapons and suggested that Metz turn to the governor-general. He also wrote to Bishop Claessens in Batavia that he had rejected Metz's suggestion of arming the raja's people to protect the parsonage because he thought Metz had unnecessarily made himself anxious, and because 'one should never let the natives see fear, because then they show themselves more presumptuous'.

In addition to this rebuff, Metz discovered that the Christian village of Lawerang (Lewerang, just north of the centre of greater Larantuka), belonging to the raja, through fear of the mountain people and encouraged by the raja's weakness, and also, Metz thought, out of superstition, had rebuilt its temple, which had been torn down ten years before. When he told the raja, the raja forbade it, but they just worked the harder. The raja forbade it a second time, but they continued. He forbade it a third time, but the villagers continued as though they had nothing to fear. Finally Metz sent crown prince Lorenzo to the raja with the request that he forbid the activity. The raja then sent Lorenzo with the message that if they did not stop, he would take back a drum and other paraphernalia. After half an hour they started again, whereupon the raja sent Don Lorenzo with some young men to retrieve the drum. Lorenzo found that the drummer was young Mige Lobato, whose education on Java as a doctor the mission had supported and who Metz thought, erroneously, had just returned from one of the villages which was threatening Larantuka. The raja was unable to punish either Lewerang or Mige out of fear of the mountain people. Fortunately there were good rains in February; so that the danger from the mountain people receded for the year.

Metz thought that Civil Commisioner Kleian and Raja Dominggo, put up to it by Kleian, had asked for auxiliary troops from Roti or Timor in order to punish the mountain people, but Metz was privately opposed to this step. He thought it unlikely that Resident Ecoma Verstege would approve, given that his predecessor H.C. Humme had been dismissed for allowing Timorese 
auxiliaries to take 132 heads and slaughter many innocent men, women and children during a punitive raid on Lewo Tolok, Lembata in September 1874. 'I was ashamed to be a Hollander when we learned what happened there in those days.' There where the scandal took place, nothing of the government's disapproval had penetrated, so that people could still come up with such an idea (Larantuka 1962-68:399-402; Steenbrink 2003:103). In fact the government forbade the further use of auxiliaries from Timor, and Resident Ecoma Verstege rejected all such requests. ${ }^{11}$

Eventually Metz learned that Ecoma Verstege was leaving his post in Timor, and he had hopes that the same would be true of Civil Commissioner Kleian, which did not prove true (Larantuka 1962-68:408). Another disappointment developed for Metz soon thereafter, when Raja Dominggo asked for a mass for the souls of former rajas. Metz asked for an explanation, and Raja Dominggo told him that Lowingo, a region in central East Flores nominally subject to Larantuka, was coming to pay tribute, which had never been done under the previous four or five rajas. Metz did not understand the connection, as the raja was asking for a mass for souls in which the help of deceased rajas would be requested for the well-being of the land. Metz explained that a black mass to help the souls of the deceased was permissible, but not a mass in order to offer them a sort of worship. They compromised on a mass invoking Heaven's blessing for the realm preceded by an invocation of the intercession of the blessed. It turned out though that Dominggo was also arranging the sacrifice of goats and pigs in order to achieve the same end. When Metz got wind of this, he gave the raja a stern lecture, but was not sure of the truth of the report. In his previous encounter with Metz, Ecoma Verstege had mentioned 'freedom of religion' in connection with the temples. Alluding back to this comment, Metz wrote, 'Freedom of religion... look there, Monseigneur, the poison administered to the native is also deadly'. He was certain that a goat had been sacrificed at the foot of the Ili Mandiri, and a pig in the great pemali temple, but he could not discover whether or not it was done on the raja's orders. At any event the sacrifices occurred with the raja's knowledge and approval, and he was present in the pemali temple.

When the mountain people arrived, the raja received them in the temple, which was decorated with a new Dutch flag and where he received 36 elephant tusks. ${ }^{12}$ The civil commissioner was also present. Shortly thereafter Christians sacrificed four pigs, and Metz said that they could only have done so on the orders of the raja, and this after he had received the priest's stern

11 Barnes 2001:296, 2005b:27-9; Dietrich 1983:41, 53 note 6, 49, 55 note 22.

12 Here the phrase 'mountain people' is not restricted to inhabitants of the Baipito villages. In accord with local usage, both Malay and Lamaholot, the term simply means people of the interior, such as those from Lowingo, as opposed to those from coastal communities. 
lecture. The mountain people had been received in the way that had been customary before there were (Dutch) priests in Larantuka. Thus the mountain people were able to see that the Raja of Larantuka and his Christians had not abandoned the religion of the ancestors. The mountain people returned calmly on the evening of 16 July. The raja remained in the temple until the evening of the 19th, clearly according to a customary prescription, of which there are parallels in Lamaholot culture. The elephant tusks were then taken to his house. They needed first to be made cool, which required further rites (and almost certainly sacrifices, if only chickens). The next day there was a polite but determined confrontation between Metz and Raja Dominggo, which eventuated in the raja admitting that he had been at fault. Metz continued to press the raja for weeks after to cease participating in such rituals (Larantuka 1962-68:409-12; Steenbrink 2003:104, 402-5).

\section{Tikar bantal}

In 1880 another war threatened. This part of the story has been taken up by Dietrich (1983:48-51), who sets out the details as an example of 'the discrepancy between the administration's interference in internal affairs, by way of "mediation", and the political structure of a native polity'. As he writes, 'It started as a mere adat issue in the context of the Demon-Paji feud with the killing of two people from Tanjung Bunga [...] by people from Baipito (Demon, subjects of Larantuka) in October 1879 , according to an adat requirement (tikar bantal)' ${ }^{13}$ Tanjung Bunga (or Flower Peninsula) is the northern tip of eastern Flores. Its people, that is those resident in the most northerly part of it, are Paji and historically subjects of the Raja of Adonara. Tikar bantal means 'mat and pillow'. The Lamaholot for 'mat and pillow' is ohã bĕlone, and the expression refers to the marriage bed, as I have been able to confirm in discussions. Arndt (1938:6) says that the expression has to do with a wish to seek revenge because of the marriage bed, turning on two myths of the origin of the Demon and Paji division. In 1871, Civil Commissioner J.M. Kluppel was asked by the Raja of Adonara for permission to undertake a mat and pillow war, before he knew the implication. There had just been a smallpox epidemic, and the raja was actually asking permission to take heads from the neighbouring Demon under the Raja of Larantuka in order to cleanse the realm. ${ }^{14}$

13 The Arabic loan word adat is a much used word in Indonesia (and the former Netherlands East Indies) standing broadly for custom and tradition.

14 Kluppel 1873:394-5. Adat was such that this war might not have endangered the treaty of friendship which the Raja of Larantuka and the Raja of Adonara had concluded just two years before in 1869 . 
On 17 March 1880 two more people from Tanjung Bunga were murdered by people from behind the Ili Mandiri, bringing the total up to five, as reported by Kleian. When summoned to provide an explanation, Raja Dominggo could provide only incomplete information. Two people from Tanjung Bunga killed previously on 20 October 1879 were victims of Lewohala, one of the Baipito. The raja had called the head of Lewohala to account and learned that they had murdered the people when they needed a sin-offering for the angry spirits because of faulty preparation of a beam for their temple. The raja then warned them to stop. On 19 December 1879, Lewohala again tried to kill someone from Tanjung Bunga. Fortunately help came in time to prevent the murder. Kleian advised the raja to try to capture the murderers and exile them. The raja answered that it was impossible for him to do so because other villages had also taken part. On 17 February 1880 another man from Tanjung Bunga was murdered by Lewohala, during a period when Kleian was on an official trip to the island of Alor. All the raja could do was order them in the strongest terms to cease and tell them that the matter would be investigated by the council of rajas on Kleian's return. After the latest murders, Kleian again turned to the raja, who said that he could do nothing because all of the villages behind the mountain were united.

Raja Kamba Begu and the kapitan of Adonara were incensed over the behaviour of the mountain people in Larantuka's territory, and only with difficulty was Kleian able temporarily to persuade them to refrain from taking revenge. Kleian then gave the names of the guilty villages, which I repeat in their present spellings: Mudakaputu, Watowiti, Riang Kemie, Lewohala, Lewoneda, Lewoloba (Leloba) and Wailolong, in other words precisely the Baipito. Kleian went on to write that the fact that these villages were in open 'rebellion' against Larantuka was proved by the fact that Lewohala and consorts on returning from the murders in Tanjung Bunga stopped at Riang Koli and stole five goats and robbed goods from the houses. Riang Koli belonged to Larantuka's territory. The Raja of Larantuka then told him the inhabitants of Lewoloba had already stolen goods from people from Larantuka in the market at Oka to the south of Larantuka. ${ }^{15}$

15 Riang Koli stands at the entrance to Tanjung Bunga, although still in Demon territory; it was founded by people from Balela, a constituent of greater Larantuka. See A.J.L. Couvreur, 'Verslag van eene dienstreis benoorden Larantoeka, 18-28 April 1907', 'Beschrijving van het rijk Larantoeka en verslag van eene reis rond Larantoeka, 13-23 Mei 1907', in: NA, Collectie 135 Le Roux, 1839-1937, nummer toegang 2.21.097.02, inv. no. 7. Oka on the other side of Larantuka is also in Demon territory, but a great way away from Riang Koli. There is still a market at Oka, and the main highway runs through it. By an historical irony, in recent decades the government has moved Leloba to Oka. 
Murder of Lewa

On 22 March the inhabitants of Waibalun and Lewolere, on the coast just southwest of greater Larantuka, killed the village head of Lewoloba, Lewa, his brother and two companions. On the 23rd the heads of these two villages appeared before the Raja of Larantuka in order to tell him about the murders. They explained that they had killed Lewa 1. because on the previous morning they had been warned by Lewa's son-in-law to watch out because Lewa was planning to attack the two villages at the first good opportunity, 2. because he was guilty of the murder of the five Paji in Tanjung Bunga, 3. because of the theft of goods belonging to people of Larantuka (that is, Riang Koli), 4. because of confiscation of fields belonging to Waibalun and Lewolere, and 5. because of taking possession of an elephant tusk belonging to someone from Lewolere. $^{16}$

Toward the end of April, Father Bernardus J.J. Mutsaers described the killing of Lewa in somewhat different, but confirming, detail. Lewa and his companions were sitting quietly in a house in Waibalun, when some men approached and shot them. Lewa had for a long time engaged the hamlets of Larantuka in apparently unjustified conflicts over their land. As soon as Lewa's death was learned in Leloba, the villagers decided to attack the coastal villages and began to strengthen themselves for war. The Resident sent some casks of powder to the raja to use in the defence. Every night guards were placed in readiness. War therefore looked unavoidable. According to a subsequent letter from Father Jacobus Kraaijvanger, Lewa had also threatened the life of crown prince Lorenzo. 'This man is then, on the orders of our great people, unexpectedly attacked [...].' Kraaijvanger's interpretation therefore implicates Raja Dominggo in the murder. In any case, there was talk of the raja shortly leaving with an organized force to punish the guilty, that is the Baipito. Kraaijvanger thought that such a move would bring the quickest solution, but said that he could not guarantee the truth of these reports and preferred not to speak to the raja about such matters (Larantuka 1962-68:450-1).

Clearly some of these reasons were added opportunistically to bolster sympathy for what was at bottom a local land dispute (Dietrich 1983:49). The last two reasons given dated to a year and a half before the murders. Kleian wrote that the village heads from their point of view had reasoned that since it was unavoidable that there would be a collision, it was better that they strike then and retain the advantage. Kleian then added that Lewa was the very person who had kept Larantuka in suspense two years before,

16 Civil commissioner Kleian, 'Dagregister v/m 18 t/m 27 Maart 1880', n.p., n.d., in: NA, Koloniën, Mailrapporten, 2.10.10, 1880, no. 333, fiche 674 . 
when they were afraid of being attacked by the villages behind the mountain, and the person who had threatened to kill the Europeans in Larantuka. His plan was then frustrated by unwillingness of some of the villages behind the mountain to participate. Kleian then observed that if it were to come to an attack, Larantuka would find it difficult to answer. They possessed almost no powder, and with rifles the situation was even worse, whereas the mountain people behind the Ili Mandiri were abundantly provided - just the point made by Metz, when he thought Kleian was underplaying the danger. 'Should the mountain people have only a little courage and in fact are serious, then it would cost them little effort to drive us from here by force.' Kleian concluded by stating that it was desirable to send a cruiser to Larantuka. ${ }^{17}$

\section{Defence of Larantuka}

By the time the situation had developed to this stage, the complications began to exceed the participants' ability to calculate or control. Apart from the villages involved, three governing entities felt their prestige challenged, the rajas of Larantuka and Adonara, as well as the government of the Residency of Timor, representing the governor-general of the Netherlands East Indies. The powerlessness of each was laid open to view. As Dietrich discerned, issues of merely local adat had become confused with issues of state. Furthermore, without intending to do so and as much as they tried to avoid it, the missionaries found themselves involved in this web of disputes.

Resident J.G.F. Riedel wrote to the governor-general on 12 April 1880 that he had heard that morning from the civil commissioner that the people from behind the Ili Mandiri planned to attack Larantuka. Many armed people had already appeared near Larantuka, but there had not yet been an encounter. The people of Larantuka were not in a position to resist; so that it might be expected that not only would the coastal villages be totally devastated, but that some of the Europeans would be murdered because of the old grievance among the mountain people caused by the opposition of Roman Catholic clergymen to 'heathenish' practices, that is to say the traditional ceremonies and practices prescribed by adat. Kupang was not in a position to offer any help despite the urgent need to take forceful measures against the rude population of Flores because no steamship or soldiers were available in Kupang. The Resident, however, did send an armed boat with thirty casks of powder confiscated from the Raja of Barnusa, Pantar, to the civil commissioner, so

17 Civil commissioner Kleian, 'Dagregister v/m 18 t/m 27 Maart 1880', n.p., n.d., in: NA, Koloniën, Mailrapporten, 2.10.10, 1880, no. 333, fiche 674 . 
that in case of need the Europeans could be taken on board. No help could be expected for Larantuka from the other (Paji) rajas of Solor (that is, Solor and Adonara) since they had long borne a grudge against the Raja of Larantuka. The civil commissioner and his family need have no fear, because the rajas of Solor would certainly protect them.

Riedel then requested a war steamship and a battalion of a hundred and twenty, consisting of forty Europeans and eighty natives from Makassar or the garrison battalion of Celebes and Dependencies, to be sent to Kupang to be available to defend Larantuka. The Raad van Indië (Council of Netherlands East Indies) took a sceptical view of the danger to Larantuka. The civil commissioner had merely asked for a cruiser, which in any case had been sent together with some powder. Although the government was willing to send forty muzzle loaders and a steamer, it was unwilling to send a detachment of troops. The Council could not determine whether the intention was to use the troops merely to defend Larantuka or to punish the mountain people. Clearly it was unwilling to consider that the two ends might be linked. Further, it could not see why the Raja of Adonara would pass up a good opportunity to take revenge by coming to the aid of Larantuka should it be attacked. Now that the civil commissioner had a cruiser available and had received powder, the Council deemed it very likely that Adonara would help. Subtleties of local culture and personalities were beyond the Council.

Another reason that counted against sending troops was that they would arrive two months after the last news from there (23 March), and the attack might well have taken place long before their arrival, whereas if the attack had not yet taken place, then surely there would be no attack and in either case the troops would have gone there unnecessarily. The Council wished to wait for further information. Meanwhile the ship Koning der Nederlanden would be flying the flag in the waters around Timor. Surely this colossal ship would make a greater impression in Larantuka than would 125 bayonets. If the aim was to punish the mountain dwellers, then a much greater number of troops would be needed against a much more numerous and stronger enemy in their own land, which was unknown to the Netherlanders. ${ }^{18}$

In May the government's steamer Sumatra arrived. After a brief discussion with the civil commissioner, the captain of the steamer decided to leave for Kupang to consult with the Resident. A couple of attacks by the raja's troops had little practical result, and the Sumatra upon returning lay in the strait and seemed to intend only to protect the Europeans in case of need. Tensions in Larantuka increased, and the Christians could hardly speak of anything other

18 'Extract uit het register der besluiten van den Gouverneur-Generaal van Nederlandsch-Indië', Buitenzorg, 10-10-1880, in: NA, Koloniën, Mailrapporten, 2.10.10, 1880, no. 376, fiche 679. 
than war. Still there was as yet no great danger, and the government provided excellently for their protection. Added to the discomfort of the missionaries was an article in the Celebes Courant by Kleian's brother-in-law, the Protestant minister of Kupang, Willem Mattheus Donselaar, stating that the missionaries had provided the occasion for the war by opposing the participation of the raja in the ceremonies at the temple and thus by implication had been mixing in government matters. This claim provoked Father Kraaijvanger's anger and the statement that they had kept themselves strictly out of the conflict. He went on to claim in a letter to the bishop that Kleian had himself ordered the murder of Lewa. ${ }^{19}$

On 12 June 1880, Resident Riedel wrote again to the governor-general to repeat his request for 120 troops, this time specifically for the defence of Larantuka, particularly the buildings of the priests and of the Franciscan nuns, which were completely isolated. He hoped that soldiers would be able to restrain the mountain people and give time to settle the dispute between the Raja of Larantuka and his mountain people with the help of rajas from Alor and Timor. He made in passing the remarkable statement that originally the mountain villages had their own 'self-governor', that is other than the Raja of Larantuka. On 4 and 28 May, the mountain people attacked Waibalun again. On the 28th they withdrew only when the armed sloop approached. When the Raja of Larantuka told Riedel that the people found the constant guarding of the Europeans burdensome, he sent fifteen policemen from Kupang. The forty muzzle loaders provided the raja had not helped, and the raja requested a thousand Timorese auxiliaries, which of course could not be permitted because of the previous experience with them.

The mountain people had attacked the houses of the priests with flaming arrows and also forced their way through the palisades into their property and left only when one of them was shot dead. The presence of troops would also allow the inhabitants of the coastal villages to work on their fields across the strait on the island of Adonara. ${ }^{20}$ The need to guard their villages prevented them from working their fields, and thus they faced famine. The Resident

19 Resident Riedel to Governor-General, Kupang, 12-6-1880, in: NA, Koloniën, Mailrapporten, 2.10.10, 1880, no. 605, fiche 701; Larantuka 1962-68:451-4b; Steenbrink 2003:87-8. Metz wrote from Makassar in April 1882, that the people in Waibalun had shut Lewa up in a house and sent a deputation to the raja to ask what they should do with him. The raja wanted to set him free, so that there would be no trouble. Metz then claimed that Kleian said, 'you have the fellow now, do not let him loose [...] I would get rid of him.' That comment reassured the raja, and Lewa was murdered. The version does not exactly fit other reports of these events, one of which claims that Kleian gave implicit rather than overt permission (Larantuka 1962-68:494, 509).

20 The Flores Strait is very narrow at Larantuka. At that time the land on the Larantuka side was poorly watered, while just opposite on Adonara there was abundant water and the land was fertile. 
acknowledged that 120 soldiers were insufficient to punish the mountain villages. In any case, he thought punishment should be the responsibility of the raja. If he were not capable of carrying it out, then the Netherlands government could declare the mountain people independent and place them under a 'heathen' raja, since the Raja of Larantuka, as a Christian, was prevented by the priests from taking part in traditional ceremonies, which was the basis of their grievance. In a meeting held at Posto in Larantuka with the other rajas, only the Raja of Lamahala, Adonara, ${ }^{21}$ whose kapitan was 'a well-known head hunter', could be persuaded to help, but only in return for a high payment, which Larantuka could not afford. Volunteers would come from Timor, if they were given permission to take heads to their hearts' desire, to plunder and to capture slaves. ${ }^{22}$ The Council again refused to authorize the sending of troops and, on the basis of a claim by the Resident that the priests had pressured the raja to prevent the mountain people choosing their own 'heathen' leader, ordered the Resident to investigate whether the admission of priests to Larantuka was damaging to peace.

Meanwhile the mountain people killed a man from Waibalun and attacked another from Pantai Besar (much closer to the centre of greater Larantuka), who escaped (Larantuka 1962-68:454c). In July Donselaar published in the Indisch Vaderland what was called a retraction of the charge against the priests, although they did not regard it as sufficient. He stated that in June the raja led 2,000 coastal and mountain dwellers in an attack on Lewoloba and Wailolong, in which there were dead and wounded on both sides, but which achieved nothing. Another attack was planned a few days later, but the force gave up halfway and returned.

In a report taken up in the 15 July issue of this year, the communication concerning the conflict between the Raja of Larantuka and a portion of his heathen subjects is incorrect to the extent that the immediate cause is not to be sought in the declaration of the Roman Catholic clergymen against the participation in heathen practices by the raja. If in the last undertaking against the enemy, in the previous month, the colours were blessed by the Church cannot be stated, but indeed that the heads at Larantuka, after the incomplete attack, unanimously came to the conclusion that victory could not be achieved without the help of the headhunting Timorese [...]. (Larantuka 1962-68:454c-5.)

In stating the matter that way, Donselaar implied that the priests were pushing for bringing in auxiliaries from Timor, which of course was the opposite of the fact. Kraaijvanger commented sourly that it could not be doubted that it

21 Pati Mangun Keropon. The Dutch had deposed his predecessor Mangu.

22 Resident Riedel to Governor-General, Kupang, 12-6-1880, in: NA, Koloniën, Mailrapporten, 2.10.10, 1880, no. 605, fiche 701 . 
was in fact the civil commissioner himself who was pushing for calling in the Timorese. On 25 September and again in mid-October Larantuka made two more unproductive attacks on Leloba. Riedel had by then been transferred to Ambon, and was replaced by W.F. Sikman. Sikman travelled to Larantuka on the Watergeus on 19 December 1880 in order to undertake an investigation ordered by the Council of the Netherlands East Indies into the circumstances there. After much effort and financial sacrifice, he managed to hold a meeting with the heads of the mountain villages at Delang Besar, on the coast north of greater Larantuka. As well as lesser leaders, three prominent heads were present, Boli Bapa, Bigi, and Merien, the first of whom because of his prominence and influence was called 'raja'. There was also a large number of armed men.

These three men presented the following grievances: 1. the murder of Lewa on Larantuka territory and the failure to return the body, 2. because the Raja of Larantuka had forbidden his people to visit the markets at Delang Besar and Tenga ${ }^{23}$ in the Baipito region, with the consequence that they could not provide the markets with fish, areca nuts, sirih peppers, tobacco and so on. Furthermore they had murdered Lewa without telling him why. The three men wanted to know why, if he had given occasion for such action, they had not been told so that they could investigate the circumstances and if necessary punish him. If he had really been guilty and they were not in a position to punish him, they could have delivered him to the Raja of Larantuka to deal with him as he saw fit. They assumed the raja had not given orders to kill Lewa and therefore blamed only Waibalun, but they could not understand then why the Raja of Larantuka did not leave the affair to the inhabitants of Waibalun and Lewoloba. They could have taken up weapons and then the Raja of Larantuka and the Baipito heads shortly thereafter could have interposed between both sides in order to bring an end to the hostilities. (Such intervention is indeed a power attributed to rajas, but was not always effective.)

The Raja of Larantuka should not have meddled in the affair, because Waibalun was guilty, and above all should not have called in other mountain people under him to destroy Lewoloba, which was justified in taking revenge. The issue should have remained a disagreement between villages and not between leaders. To the question whether they wanted to make peace with the Raja of Larantuka, they replied that they would be happy to, but that they would not be the first to offer the hand of friendship because they were not subjects of the Raja of Larantuka and furthermore they were not the guilty party - which was in fact the people of Larantuka - and finally because their trust had been betrayed. About ten years earlier, the inhabitants of Riang Kemie, bribed by Waibalun to do so, had murdered eight people from the

23 This name seems to refer to Tengah in northern Larantuka, which is definitely not on Baipito territory. 
coastal village Lewolere under Larantuka. The Raja of Larantuka punished Riang Kemie, and they had stood by him because they thought Riang Kemie deserved it. When Riang Kemie thought it could no longer resist, its leaders raised a white flag. The Raja of Larantuka ordered an end to the fighting, and prominent men of the village approached the raja in order to learn the conditions of the capitulation. After the raja had told them, they wanted to return, but instead, under the eyes of the raja, they were treacherously murdered. If the Raja of Larantuka wanted to end the enmity and live in friendship with them, let him show it by removing the prohibition on visiting the markets.

On his return to Larantuka, Sikman told the Raja of Larantuka the results of his conversation and advised him to send one of his kapitan as quickly as possible to the Baipito heads in order to bring an end to hostilities and also to revoke the prohibition on visiting the markets. The raja and his kapitan were not to be persuaded. One of the kapitan who was better spoken than the raja explained that the villagers behind the Ili Mandiri had begun hostilities when they killed the subjects of the Raja of Adonara. When the civil commissioner heard about it, he called the Raja of Larantuka and his kapitan to come to talk over the killings. He suggested that they punish the murderers in support of the Raja of Adonara. The Raja of Larantuka then called the Ili Mandiri heads to investigate the events. These heads replied that the murders were in accord with customary usage of tikar bantal as a way of providing a sin-offering to their gods whenever an epidemic broke out or in times of drought or other such catastrophes. The Raja of Larantuka conveyed this answer to Kleian, who advised him to let the mountain dwellers know that such practices were forbidden. When more subjects of the Raja of Adonara were nevertheless murdered, Kleain repeated his order to stop. Finally the Raja of Adonara came to complain. Kleian called the Raja of Larantuka and ordered him to punish the mountain dwellers in order to satisfy the Raja of Adonara. The Raja of Larantuka answered that the Raja of Adonara could get satisfaction by killing some of the people behind the Ili Mandiri. Kleain replied that it was the responsibility of the Raja of Larantuka to punish his own people, and advised the Raja of Adonara to be patient because the Raja of Larantuka could not possibly put his hands on the guilty parties at the moment.

The raja and his party then went to the house of the Raja of Larantuka, where his kapitan were waiting. These men proposed to the Raja of Adonara that they go together to Delang or Watumanu or Weri and kill some people from behind the Ili Mandiri. The Raja of Adonara, however, said that he would first speak to Kleian about the proposal. About six days later they received the news that people of Waibalun had surrounded one of the leaders from behind the Ili Mandiri with three of his followers and intended to kill him. They at once sent someone to prevent the murders, but he arrived too late. Neither the raja nor his kapitan had ordered the killings. Three days 
later the people of Waibalun brought Lewa's head to the Raja of Larantuka. In keeping with established adat the raja wished to send a sabre to the Raja of Adonara as a sign that with that weapon the murder of the five subjects of Adonara had been revenged. Larantuka's real purpose in sending the sabre was however to deceive the mountain people into the misconception that not Larantuka, but Adonara had carried out the murder at Waibalun and thus to shove all of the guilt on to Adonara. The Raja of Adonara, however, refused to receive the weapon, saying that Larantuka and not Adonara had murdered the men at Waibalun as punishment for murder of the five subjects of Adonara. ${ }^{24}$ As a consequence of this refusal, Larantuka found itself in great embarrassment. ${ }^{25}$

When Resident Riedel visited Larantuka two months later on the Koning der Nederlanden, he called the rajas on board for an investigation and asked them if they were ready to make peace. However, no one had the courage to meet the mountain people, and the Raja of Adonara declared himself the least prepared to do so because the first murders had been on his territory. The Raja of Larantuka then asked for weapons and ammunition to use to protect the Europeans in Larantuka, and Riedel promised fifteen armed policemen as well as the munition. Don Dominggo agreed to house the policemen. Then the Resident asked for the heads of the murdered men, which were then taken on board the ship and wrapped in old cotton. No one knew why the Resident did this.

A few days after Riedel left, the Sumatra arrived. The officers said that it had been sent to help them in their war with the mountain people. The next day the Raja of Larantuka and his officers decided to set out against Lewoloba. The captain of the ship, however, forbade any hostilities until the civil commissioner, who was then on Lembata, returned. The next day the raja passed on word that there was a war at Waibalun. The captain sent troops to Waibalun, but when they arrived the enemy had already gone. The people of Waibalun had not begun hostilities, because they had been forbidden to do so. The next day the raja and the just returned civil commissioner were informed by the captain of the Sumatra that it was leaving for Kupang and would be back in seventeen days. The captain asked the raja to keep 2,000 armed men in readiness during the interval. When the Sumatra returned on

24 This statement of the case was written out for the Resident by two kapitan of Larantuka, Franciscus Dias Viera and Hari da Silva. They reported that the Raja of Adonara refused the sabre, and asked instead for a stone and a small basket of earth, which the Raja of Larantuka refused (Franciscus dias Vieira and Hari da Silva, 'Oorsprong van het geschil tusschen den radja van Larantoeka en het achter de Illimandiri wonende bergvolk', Larantuka, 22-12-1880, in: NA, Koloniën, Mailrapporten, 2.10.10, 1882, no. 1057, fiches 1210 and 1211).

25 Resident Sikman to Governor-General, Timor, 19-1-1881, in: NA, Koloniën, Mailrapporten, 2.10.10, 1881, no. 285 , fiche 831 . 
the appointed day, he told the raja that Resident Riedel had forbidden the ship to meddle in Larantuka matters. This statement took the raja aback, because the troops were ready and waiting, and the captain had promised to help. Therefore the raja and his kapitan told the civil commissioner that now that the population had been called up it was better to move against the enemy than to send them uselessly home.

This plan was conveyed to the captain, who approved it and promised to take the Sumatra to Oka to provide assistance. Two days later it arrived in the vicinity of the enemy around the time of the attack, so that no fight took place and everyone returned home. A few days afterwards the mailboat arrived with the new Resident (Sikman). After the Resident had come ashore, it was agreed that the kapitan of Lamahala, Adonara, and the kapitan of Larantuka should attempt to meet the inhabitants of Lewotala, which is situated near the enemy villages, with the intention of using this route to find a solution to the issue. The enemy, however, was not interested in negotiating; so the tensions continued. The two delegates told the Netherlanders that they did not dare to approach the enemy leaders and that the raja could not rescind his prohibition on visiting the market for fear that the mountain people would kill anyone who went there.

Sikman then told the raja that the hostilities had lasted long enough and that he wanted a speedy end to them. The raja was responsible for peace and order. If he was not able to govern the people of Ili Mandiri (that is Baipito), then the Resident had no choice but to appoint Boli Bapa as Raja of Ili Mandiri. On hearing that, the raja and his kapitan said that they would send someone to the Ili Mandiri leaders in order to end the hostilities and that they would remove the ban on the markets. Because its coal was low the ship, with the Resident, had to leave for Kupang the next day. Sikman stated that he could find no evidence that the priests had meddled in the affair. He also reported that he regarded the question as ended and had taken all of the policemen back to Kupang, while leaving the armed ship there. ${ }^{26}$ Before he left Larantuka, Resident Sikman took Father Zelis aside and asked him to tell the Raja of Larantuka to respect the religion of the mountain people. Zelis replied that he would do what he could to encourage peace, but he would not promise to encourage the raja to restore the korke (Larantuka 1962-68:460).

26 Resident Sikman to Governor-General, Timor, 19-1-1881, in: NA, Koloniën, Mailrapporten, 2.10.10, 1881, no. 285, fiche 831; Franciscus dias Vieira and Hari da Silva, 'Oorsprong van het geschil tusschen den radja van Larantoeka en het achter de Illimandiri wonende bergvolk', Larantuka, 22-12-1880, in: NA, Koloniën, Mailrapporten, 2.10.10, 1882, no. 1057, fiches 1210 and 1211. 


\section{Complications and implications}

Dietrich (1983:50-1) has described the events through 1883. Having received stern letters from the Resident, Kleian undertook secret negotiations with the Baipito heads, but the raja and his kapitan, angered at being bypassed, refused to cooperate. They wrote secretly to the Resident and said that the civil commissioner was himself the cause of the war (Larantuka 1962-68:465). Sikman did not get that letter because he was already on his way to Larantuka. The raja refused to accompany him to Delang for a meeting with the mountain leaders. The next day the Resident had a meeting with the civil commissioner and the rajas, among others. At this meeting the Raja of Larantuka and his kapitan broke with their silence and timidity and spoke very harshly, setting out how everything had happened and pointing out Kleian's share of the responsibility for the war. The Resident then required Kleian to take down all the details accurately. After that meeting the Resident, accompanied by the captain of the Watergeus and the civil commissioner, visited the priests. Kleian, who hardly spoke, was as white as a corpse (Larantuka 1962-68:467).

By early 1881, the Resident thought that peace was at hand, but hostilities between Waibalun and Lewoloba resumed in February 1882 at the market in Delang, when Waibalun killed some Baipito residents. Baipito retaliated by attacking villages in northern Larantuka, that is people who had nothing to do with the land dispute, and threatening Posto, the centre of greater Larantuka (Larantuka 1962-68:495). The new Resident, Samuel Roos, who had once served as civil commissioner in Larantuka, held a conference in May 1882, in which he was extremely rude and made demands that peace be concluded, backed by a threat to depose and exile the raja (Larantuka 1962$68: 508-9,512,531)$. The raja's ability to conclude such a peace was blocked, however, by the anger of the Baipito villagers. ${ }^{27}$ Don Dominggo responded to this treatment by writing to the Council setting out his views on the causes of hostility and accusing Kleian of corruption and repeating the claim that

27 'Kort verslag nopens den stand van zaken en het personeel in de residentie Timor, over de maand Maart 1881', Timor, 31-3-1881, in: NA, Koloniën, Mailrapporten, 2.10.10, 1881, no. 422, fiche 863; 'Kort verslag nopens den stand van zaken en het personeel in de residentie Timor over de maand Mei 1881', n.p., n.d., in: NA, Koloniën, Mailrapporten, 2.10.10, 1881, no. 566, fiches 503 and 504; telegram Resident Sikman to Governor-General, Timor, 15-2-1882, in: NA, Koloniën, Mailrapporten, 2.10.10, 1882, no. 222, fiche 1072; 'Kort verslag betreffende den toestand en het personeel in de residentie Timor en onderhoorigheden over de maand February 1882', Kupang, 28-2-1882, in: NA, Koloniën, Mailrapporten, 2.10.10, 1882, no. 314, fiches 1006 and 1007; Resident Roos to Governor-General, Kupang, 31-3-1882, 'Kort verslag betreffende den toestand en het personeel in de residentie Timor en onderhoorigheden over de maand Maart 1882', in: NA, Koloniën, Mailrapporten, 2.10.10, 1882, no. 420, fiche 1186; telegram, Resident Roos to GovernorGeneral, Timor, 2-6-1882, in: NA, Koloniën, Mailrapporten, 2.10.10, 1882, no. 585, fiche 1145. 
Kleian had instigated the attack on Lewa. Among the correspondence these charges provoked was a report by Resident Roos accusing Dominggo of lying and defending Kleian's competence and integrity. ${ }^{28}$

On 11 April 1884, Resident Roos was able to report that hostilities between the mountain people behind Ili Mandiri and the coastal people had ceased and that peace had been concluded between them on 22 March. ${ }^{29}$ This improvement resulted from conflict among the Baipito villages (Larantuka 1962-68:589). Roos soon left Timor and Kleian Larantuka. By the time peace came, attention had shifted far from the original slaughter of dependants of the Raja of Adonara in Tanjung Bunga by villagers of Baipito and their concern about the beams in their korke. Other pressing issues in the Solor Strait began to draw attention. Dietrich (1883:51), however, concludes, 'It seems that for a large part the short-cutting of adat procedures contributed to the extent assumed by this conflict'. From the point of view of the raja and his captains, and perhaps others as well, the military intervention by the Dutch in what otherwise would have been purely a local matter may have appeared irrational. The colonial officials demanded that peace be restored and held the Raja of Larantuka in particular responsible, even though his ability to intervene as directed was seriously circumscribed, as demonstrated by the failures of his various attempts to comply. Don Dominggo's position was made even more difficult in that, although he was formally a self-governor and ambiguously sovereign, the Netherlands authorities attempted to reduce his role to an administrative function. The civil commissioner and Residents were hampered in their efforts to ensure peace by the reluctance of the central authorities to support the expenses required for truly effect military involvement (Dietrich 1983:52-3).

Whether Civil Commissioner Kleian was corrupt, as alleged by the Raja of Larantuka, or as implacably anti-Catholic as the priests thought, I cannot judge on the basis of the evidence I have seen. ${ }^{30}$ The difference of religion between the priests and the occupants of the office of Resident of Timor certainly provided a fertile bed for suspicion, despite efforts on both sides to

28 'Maleische brief gerigt aan den algemeenen secretaris gedagteekend Larantoeka 30 Mei 1882 van zekeren Domingos en volgens diens beweren geschreven namens de bevolking van Larantoeka', in: NA, Koloniën, Mailrapporten, 2.10.10, 1882, no. 1057, fiche 1210; Resident Roos to Governor-General, Kupang, 13-10-1882, in: NA, Koloniën, Mailrapporten, 2.10.10, 1882, no. 1057, fiche 1210 .

29 Telegram, Resident Roos to Governor-General, Kupang, 3-4-1884, in: NA, Koloniën, Mailrapporten, 2.10.10, 1884, no. 286, fiche 1425: Koloniaal verslag 1884:26, 1885:27.

30 Kleian's defence against Raja Dominggo's charges might have appeared acceptable to the higher authorities; at any event they took no steps against him in response to the allegations (Kleian to Resident of Timor, Larantuka, 8-9-1882, in: NA, Koloniën, Mailrapporten, 2.10.10, 1882, no. 1057, fiche 1210). 
maintain cordial and cooperative relationships. Although the priests repeatedly defended themselves, in private and in public, from the charge of interfering in government matters, that defence was difficult to maintain. On the one hand colonial officers asked them to use their influence to persuade the Raja of Larantuka to take the steps the officials wanted, which necessarily meant involvement. On the other hand the priests' attitude toward traditional ceremonies and temples placed the rajas of Larantuka in precisely the ambiguous and difficult position that provoked conflicts with the mountain dwellers. These conflicts had governmental implications and led the priests to regard the rajas as vacillating and unreliable, for rather different reasons than those which led the colonial authorities to take the same view. There was as well the issue of human sacrifice through headhunting which complicated matters even more. It complicated, for example, the position of the Protestant officials, who were in the ironic position of defending the religious freedom of 'heathens' - in this case not just 'heathens', but 'heathens' who killed people and took heads as part of their religious practices.

The rajas were caught between the mountain people and the coastal people, to some extent between the Demon and the Paji, between their own people and the Europeans, and most certainly between the priests and the colonial authorities. The priests were caught between their obligations, as they saw them, to their religion and to the Christians and the expectations of the colonial authorities. The local colonial authorities were caught between the expectations of the higher authorities and local circumstances beyond their control, aggravated by the fact that the higher authorities could fail to support the measures they took and to supply the resources they requested. The local people were caught in the instability created by these circumstances and the threats to their own lives. Don Dominggo died in 1887, and his successor Don Lorenzo was eventually deposed and exiled (in 1904) in the first decisive act in the Residency to introduce a new interventionist form of control and to replace the last remnants of an earlier 'hands off' policy of regional government (Barnes 2005b, 2008).

\section{Acknowledgements}

I conducted research for this article while at the International Institute for Asian Studies, Leiden, the Netherlands. The research was supported by a grant from the Research Committee on South East Asian Studies of the Association for South-East Asian Studies, UK. I am very grateful to these institutions and to the staff of these institutions for their generous assistance. I am also grateful to the Asia Research Institute, National University of Singapore, which provided facilities for completing this article. 


\section{References}

\section{Unpublished sources}

Koninklijk Instituut voor Taal-, Land-en Volkenkunde, Leiden

Collectie 40 G.P. Rouffaer, H 673

Nationaal Archief, The Hague

Collectie 135 Le Roux, 1839-1937, nummer toegang 2.21.097.02

Ministerie van Koloniën, 1850-1900 (1932), Index op de Mailrapporten, 1869-1899, nummer toegang 2.10 .10

Published sources

Arndt, Paul

1938 'Demon und Padzi, die feindichen Brüder des Solor-Archipels', Anthropos 38:1-58.

1940 Soziale Verhältnisse auf Ost-Flores, Adonare und Solor. Münster: Aschendorffschen Verlagsbuchhandlung. [Anthropos Ethnologische Bibliothek

1951 4, 2. Heft.]

Barnes, R.H. Religion auf Ostflores, Adonare und Solor. Wien-Mödling: St. Gabriel. [Studia Instituti Anthropos 1.]

2001

'Alliance and warfare in an eastern Indonesian principality; Kédang in the last half of the nineteenth century', Bijdragen tot de Taal-, Land-en Volkenkunde 157:271-311.

2005a 'The murder of Sengaji Begu; A turning point in Dutch involvement in the Solor Archipelago', Masyarakat Indonesia 31:1-17.

2005b 'Hongi Hinga and its implications; A war of colonial consolidation in the Timor Residency in 1904', Bijdragen tot de Taal-, Land-en Volkenkunde 161:1-39.

2005c 'A ritual resurgence in eastern Indonesia', Anthropos 100:359-77.

2007 'A legendary history in Witihama, eastern Adonara, Indonesia; An enduring context for disagreement', Moussons 11:7-31.

2008 'Raja Lorenzo II; A Catholic kingdom in the Dutch East Indies', IIAS Newsletter 47:24-5.

Bubandt, Nils O.

2004 'Towards a new politics of tradition? Decentralization, conflict, and adat in eastern Indonesia', in: Nils O. Bubandt and Andrea K. Molnar (eds), Dietrich, Stefan Mengahadapi konflik; Indonesia Timur diantara decentralisasi dan kerusuhan, pp. 11-30. [Special edition Jurnal Antropologi Indonesia 28-74.]

'Flores in the nineteenth century; Aspects of Dutch colonialism on a non-profitable island', Indonesian Circle no. 31 (June). 
'Tjeritera Patigolo Arkian; Struktur und Variation in der Gründungsmythe des Fürstenhauses von Larantuka (Ostindonesiën)', Tribus; Jahrbuch des Linden-Museums 44:112-48.

1997 Kota Rénya, 'Die Stadt der Köningin'; Religion, Identität und Wandel in einer ostindonesischen Kleinstadt. Habilitationsschrift, Universität München.

Ezermann, H.E.K.

1917 'Timor en onze politieke verhouding tot Portugal sedert het herstel van het Nederlandsch gezag in Oost-Indië, Koloniaal Tijdschrift 6-1:865-96, 1047-78, 1209-32.

Heyman, Albertus

1895 De Timor-tractaten (1859 en 1893). Leiden: Van Doesburgh. [PhD thesis, Rijksuniversiteit Leiden.]

Heynen, F.C.

1876a Het Christendom op het eiland Flores in Nederlandsch Indië. 's-Hertogenbosch: Van Gulick. [Studiën op Godsdienstig, Wetenschappelijk en Letterkundig Gebied 8, 8.]

1876b Schetsen uit de Nederlandsch-Indische missie; De kerkelijke statien op Flores. 's-Hertogenbosch: Bogaerts.

1876c Het rijk Larantoeka op het eiland Flores in Nederlandsch Indië. 's-Hertogenbosch: Van Gulick. [Studiën op Godsdienstig, Wetenschappelijk en Let-

Kluppel, J.M. terkundig Gebied 8, 6.]

1873 'De Solor-Eilanden', Tijdschrift voor Indische Taal-, Land- en Volkenkunde (TBG) 20:378-98.

Koloniaal verslag

$1884 \quad$ Koloniaal verslag 1884. 's-Gravenhage: Algemeene Landsdrukkerij.

1885 Koloniaal verslag 1885. 's-Gravenhage: Algemeene Landsdrukkerij.

Larantuka

[1962-68] Larantuka 1860-1863; Drie jaren missie-werk door twee wereld-heren. VerzaPampus, Karl-Heinz meld door Br. Petrus [Laan] SVD. Ende: n.n. [Typescript.]

1999 Koda Kiwã; Dreisprachiges Wörterbuch des Lamaholot (Dialekt von Lewolema). Stuttgart: Steiner. [Abhandlungen für die Kunde des Morgenlandes 52,4 .]

Steenbrink, Karel

2003 Catholics in Indonesia 1808-1942; A documented history, Volume 1: A modest recovery 1808-1903. Leiden: KITLV Press. [Verhandelingen 196.]

Tractaat

1860 'Koninklijke goedkeuring van het tractaat omtrent de regeling van de grenzen der Nederlandsche en Portugeesche bezittingen op Timor en onderhoorige eilanden', in: Staatsblad van Nederlandsch-Indië no. 101, no. 58.

Vatter, Ernst

1932

Ata Kiwan; Unbekannte Bergoölker im tropischen Holland: Ein Reisebericht. Leipzig: Bibliographisches Institut. 